on physical characteristics, genetical and evolutionary features and blood grouping. Rocent advances in the field of human biology have been incorporated. The influence of environment on evolutionary change is one of the more interesting aspects of this investigation; but the rather simplified explanation about the unspecialized nature of the human body is perhaps not the entire story. One hesitates to attribute the lack of specialization entirely to man's achievement of a 'culture', which rendered unnecessary any major evolutionary alteration to his physique. The chapter on racial origins is refreshing in view of the cumbersome terminology still being advanced by some physical anthropologists. The author is surely right in suggesting that only two genera should be distinguished in the early hominids, but it would have been interesting to see the single genus line expostulated. Not everyone would accept the wide geographical range of these early hominids, but the racial and geographical range of Homo erectus seems incontestable. The position in the evolutionary sequence of the Great Interglacial European representatives still tends to be avoided. The emergence and appearance of Homo sapiens throughout the world make up the remainder, and bulk, of this useful handbook.

\section{Ramsay Memorial Fellowships}

The Ramsay Memorial Fellowships Trustees have made the following awards of new fellowships in chemistry for the year 1965-66: General (British) Fellowship to Mr. Moti Lal at the University of Strathclyde; a Glasgow Fellowship to Mr. J. A. Miller at the University of Cambridge; a Canadian Fellowship to Dr. J. F. Skinner at University College, London; a Japanese Fellowship to Dr. H. Suzuki at Bedford College, London; a Spanish Fellowship to Dr. J. A. Burriel Lluna at the Imperial College of Science and Technology, London; a United States Fellowship to Dr. L. L. Ames. The Trustees have renewed the following fellowships for the same year to: Dr. R. D. Levine (General (British) Fellowship) at the University of Oxford; Dr. T. W. Dingle (Canadian Fellowship) at the University of Oxford; Mr. M. J. Baillie (Glasgow Fellowship) at the University of Cambridge; Miss Margaret Kershaw (New Zealand Fellowship) at the University of Reading.

\section{The Harkness Fellowships of the Commonwealth Fund-New York}

Thirty Harkness Fellowships of the Commonwealth Fund-New York are offered each year for study and travel in the United States. Candidates must be British subjects who are citizens of the United Kingdom or present Colonies by birth or by naturalization. Candidates must be between 21 and 32 years of age on September 1 , 1966. By that date they should have a degree from a university or the equivalent in qualifications conferred by professional bodies, or an attested level of professional competence in the public service, the professions, the creative arts, journalism, business, industry, or other comparable careers. Candidates who propose an academic career must have experience of post-graduate research. The fellowships are tenable for between 12 and 21 months. Round-trip passages to the United States are provided. Emoluments include living and family allowances, travel in the United States, tuition and research expenses, and other allowances. Selection of Fellows for nomination to the Fund is at the sole discretion of the Committee of Award, which will conduct interviews at Harkness House, London, in February, 1966. Further information and details of the fellowships can be obtained from the Warden, Harkness House, 38 Upper Brook Street, London, W.1. Application, on forms provided by the Fund, must reach Harkness House before November 11.

THE following have been elected to fellowships at Churchill College from October 1, 1965 (Title B): Dr.
J. A. Miller, to a senior research fellowship; Dr. J. B. Gibson (Sheffield), to a senior research fellowship.

Belfast

THE following lecturers have been appointed: R. N. Hughes (psychology); Dr. J. T. Patterson and Dr. D. J. Stewart (agricultural bacteriology); Dr. B. G. J. Thompson (mechanical engineering).

Newcastle upon Tyne

THE following appointments have been made: Professors, Dr. R. B. Clark (zoology); Dr. P. Collison (social studies); Dr. J. Brown (psychology); Readers, Dr. T. Scratcherd (physiology); Dr. J. G. Buchanan (organic chemistry).

\section{London}

Dr. S. CoHEN has been appointed to the chair of chemical pathology tenable at Guy's Hospital Medical School. The following readers have also been appointed: Dr. P. G. Hall (geography, tenable at the London School of Economics and Political Science); Dr. M. M. R. Williams (nuclear engineering, tenable at Queen Mary College); Dr. H. Sawistowski (chemical engineering, tenable at the Imperial College of Science and Technology); Dr. D. W. Turner (organic chemistry, tenable at the Imperial College of Science and Technology). The title of reader in mathematics has been conferred on Dr. L. M. Hocking in respect of his post at University College.

\section{Announcements}

A symposium on "Man-made Lakes", organized by the Institute of Biology, will be held at the Royal Geographical Society during September 30-October 1. Further information can be obtained from the Institute of Biology, 41 Queen's Gate, London, S.W.7.

THE fourteenth autumn meeting of the Society for Water Treatment and Examination will be held at Leamington Spa during September 29-October 1. Further information can be obtained from Mr. A. W. H. MeCanlis, 41 Carshalton Road, Sutton, Surrey.

A symposium on "Management in Research Organizations" will be held at the Manchester College of Science and Technology on September 29. Further information can be obtained from the Registrar, Manchester College of Science and Technology, Manchester 1.

A symposium on "Genetic and Environmental Factors in Human Ability", arranged by the Eugenics Society, will be held in University College, London, during September 30-October 1. Further information can be obtained from the General Secretary, the Eugenics Society, 69 Eccleston Square, London, S.W.1.

THE second international symposium on "Inhaled Particles and Vapours", arranged by the British Occupational Hygiene Society, will be held in Cambridge during September 28-October 1. Further information can be obtained from Dr. J. S. McLintock, Medical Services, National Coal Board, Hobart House, Grosvenor Place, London, S.W.1.

Foratom (Forum Atomique Européen) Congress 1965 will be held at Frankfurt-on-Main during September 29 October 1, and will consist of a discussion meeting dealing with the subject "Nuclear Energy in Europe-from Raw Material to Electricity Grid". The state of development and future prospects of the use of atomic power for energy supply in Europe will be surveyed and there will be four sections dealing with, respectively: fuels, including uranium sources and fuel elements; present types of nuclear power stations; use of the nuclear power station in the electricity grid; and conclusions concerning the future utilization of nuclear energy in Europe. Further information can be obtained from Foratom-Congress 1965 , 5300 Bonn an Rhein, Koblenzer Strasse 240. 